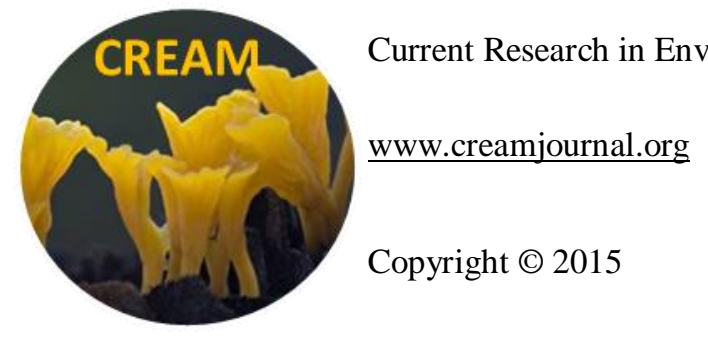

Article

CREAM

Copyright $\odot 2015$

Doi 10.5943/cream/5/4/11

\title{
Frequency of marine fungi on animal substrates along West coast of India
}

\section{Nambiar GR* and Raveendran K}

Department of P.G. Studies \& Research in Botany, Sir Syed College, Taliparamba, Kerala- 670142, India

Nambiar GR, Raveendran K 2015 - Frequency of Marine Fungi on Animal Substrates along West Coast of India. Current Research in Environmental \& Applied Mycology 5(4), 394-397, Doi $10.5943 / \mathrm{cream} / 5 / 4 / 11$

\begin{abstract}
The examination of decaying animal substrates collected from the beaches along west coast of India resulted in the identification of 22 species of marine fungi comprising 13 ascomycetes, 1 basidiomycete and 8 asexual fungi. Matsusporium tropicalis (14.63\%) and Trichocladium achrasporum (12.20\%) were most frequently encountered.

Keywords - calcareous - incubation period - isolation

\section{Introduction}

Fungi in general are able to degrade a wide range of recalcitrant biological molecules and particularly in coastal ecosystems, fungal activity may be critical in the early stages of biodegradative pathways. Marine fungi are a worldwide ecological group, but distinct in their geographical distribution and the substrata on which they are found (Jones et al. 2006). Currently about 530 species of higher marine fungi are known from different parts of the world (Jones et al. 2009). A recent checklist of marine fungi known from India (Borse et al. 2013) listed 185 species (139 ascomycetes, 3 basidiomycetes and 43 asexual fungi). Although they grow on diverse substrata (sea weeds, sea grasses, dead animal substrates, wood, algae etc.), it is the woody substrata which support the majority of the known marine fungi (Kohlmeyer \& Kohlmeyer 1979, Nambiar \& Raveendran 2012). Hence, an attempt to study the marine fungi colonizing decaying animal substrates were carried out and the results are presented here.
\end{abstract}

\section{Material \& Methods}

\section{Collection and treatment of wood samples}

Decaying animal substrates like calcareous shells, 'chicken bone', endoskeleton of Seibia, feathers and mollusk were collected from the beaches of Maharashtra (Ratnagiri), Goa (Bambolim), Karnataka (Surathkal), Kerala (Chal, Adikadalayi, and Cochin) and Tamil Nadu (Kanyakumari) along west coast of India during 2007-2010. Calcareous tubes of wood borers were also subjected to the isolation of marine fungi. After thorough washing, the wood samples were examined for sporulating structures such as conidia, perithecia, pycnidia and basidiomata under stereomicroscope. The fruiting structures were removed with a fine forceps. The isolated fungi were examined under a compound microscope. The permanent mounts of the isolated fungi were 
prepared and kept in the mycology laboratory of the college. Later, the samples observed under stereomicroscope were incubated in polythene bags at room temperature. Periodical isolation of marine fungi from these samples was carried out for 1 to 2 years. Identifications of marine fungi were done using taxonomic keys (Kohlmeyer \& Kohlmeyer 1979, Raveendran \& Manimohan 2007, Jones et al. 2009). The marine fungi thus isolated were tabulated and recorded (Table. 1).

\section{Presentation of data}

Percentage frequency of occurrence $(F O)=$ Number of isolates of a particular species divided by total number of wood samples supporting marine fungi x 100 .

On the basis of percentage frequency of occurrence, the marine fungi were classified as most frequent $(>10 \%)$, frequent $(5-10 \%)$, occasional $(3-5 \%)$ and rare $(<3 \%)$.

Percent relative abundance $(\mathrm{RA})=$ Number of isolates of a particular species obtained divided by total number of fungal isolates obtained from all the location X 100.

Table I List of marine fungi on various animal substrates along west coast of India.

\begin{tabular}{|c|c|c|c|c|c|c|c|c|c|}
\hline Name of fungi & $\begin{array}{l}\overline{0} \\
\bar{d} \\
0\end{array}$ & 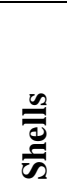 & 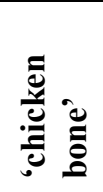 & 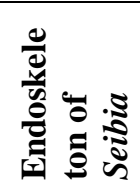 & & 离 & 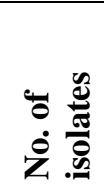 & O & 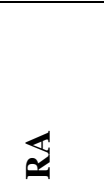 \\
\hline Ascomycota & & & & & 4 & & 4 & 9.76 & 7.14 \\
\hline $\begin{array}{l}\text { Antennospora quadricornuta (Cribb } \\
\text { and J.W. Cribb) Johnson }\end{array}$ & & & & & & & & & \\
\hline $\begin{array}{l}\text { Arenariomyces majusculus Kohlm } \\
\text { and Volk. -Kohlm. }\end{array}$ & 1 & & & & 1 & & 2 & 4.88 & 3.57 \\
\hline Arenariomyces parvulus Jorg. Koch & 1 & & & & & & 1 & 2.44 & 1.79 \\
\hline Corollospora cinnamomae Koch & & 2 & & & & & 2 & 4.88 & 3.57 \\
\hline $\begin{array}{l}\text { Corollospora gracilis Nakagiri and } \\
\text { Tokura }\end{array}$ & 1 & & & & & & 1 & 2.44 & 1.79 \\
\hline $\begin{array}{l}\text { Corollospora indica Prasanarai, } \\
\text { Ananda and Sridhar }\end{array}$ & 1 & & & & & & 1 & 2.44 & 1.79 \\
\hline Corollospora intermedia Schmidt & & 1 & 1 & & & 2 & 4 & 9.76 & 7.14 \\
\hline Corollospora maritima Werdermann & & & & & & 1 & 1 & 2.44 & 1.79 \\
\hline $\begin{array}{l}\text { Haiyanga salina (Meyers) Pang and } \\
\text { E.B.G. Jones }\end{array}$ & & 3 & & & & & 3 & 7.32 & 5.36 \\
\hline Halosphaeria appendiculata Linder & & 1 & & & & & 1 & 2.44 & 1.79 \\
\hline Lulworthia opaca like & & 6 & & & & & 6 & 14.63 & 10.71 \\
\hline Nimbospora octane Kohlm. & & 1 & & & & & 1 & 2.44 & 1.79 \\
\hline Torpedospora radiata Meyers & & & 1 & & 2 & & 3 & 7.32 & 5.36 \\
\hline Basidiomycota & & & & & 1 & & 1 & 2.44 & 1.79 \\
\hline Nia vibrissa Moore and Meyers & & & & & & & & & \\
\hline Mitosporic fungi & & & & & & 1 & 1 & 2.44 & 1.79 \\
\hline $\begin{array}{l}\text { Halenospora varia (Anast.) E.B.G. } \\
\text { Jones }\end{array}$ & & & & & & & & & \\
\hline $\begin{array}{l}\text { Matsusporium tropicalis (Kohlm.) } \\
\text { E. B G Jones and K L Pang }\end{array}$ & & 2 & 1 & 2 & & 1 & 6 & 14.63 & 10.71 \\
\hline $\begin{array}{l}\text { Moleospora maritima Abdel-Wahab, } \\
\text { Abdel_Azia and Nagahama }\end{array}$ & & 2 & & & & & 2 & 4.88 & 3.57 \\
\hline Monodictys pelagica (T.W. Johnson) & & & & & & & & & \\
\hline E.B.G. Jones & & 1 & & & 1 & & 2 & 4.88 & 3.57 \\
\hline Periconia prolifica Anast. & 1 & & & 1 & & 1 & 3 & 7.32 & 5.36 \\
\hline $\begin{array}{l}\text { Trichocladium achrasporum (Meyers } \\
\text { and R.T. Moore) Dixon }\end{array}$ & & 3 & & & 1 & 1 & 5 & 12.20 & 8.93 \\
\hline
\end{tabular}

Where FO is percent frequency of occurrence and RA is percent relative occurrence

Total number of marine fungal isolates $=56$; Total number of samples supporting marine fungi $=41$ 


\section{Results \& Discussion}

Twenty two species of marine fungi were obtained from animal substrates along the west coast of India. These comprised of 13 ascomycetes, 1 basidiomycete and 8 asexual fungi. Matsusporium tropicalis (14.63\%) and Trichocladium achrasporum (12.20\%) were most frequently encountered. 8 species were frequent, 5 species were occasional and 7 species were rare in occurrence on these substrata.

Calcareous shells supported maximum (12) number of marine fungi and the endoskeleton of Seibia the minimum (2). While 7 marine fungi were isolated from mollusk shells, 6 from feathers, 5 from borers and 3 from the 'chicken bone'. None of the fungi were found common to all type of animal substrates screened for marine fungi. Matsusporium tropicalis was common to 4 substrates i.e. shells, 'chicken bone', endoskeleton of Seibia and feathers. Corollospora intermedia, Periconia prolifica and Trichocladium achrasporum were common to 3 substrates, Haiyanga salina, Arenariomyces majusculus, Monodictys pelagica and Torpedospora radiata were common to any two substrate. Majority of the marine fungi i.e. 15 species were from any one of the animal substrates.

Calcareous animal shells are most unique habitats for marine fungi. Shells collected from intertidal beaches often reveal dense colonization by fungal hyphae (Raghukumar 1996). Calcareous tubes of wood borers present within wood and shells of barnacles and mollusk's frequently harbour fungal mycelia (Kohlmeyer 1969). Hohnk (1969) described the characteristic mycelial morphology of fungi in such shells.

Rees and Jones (1985) reported 9 fungi on the bird feathers collected from the coastal sand dunes of Denmark. 23 marine fungi were isolated from calcareous materials by Kohlmeyer and Kohlmeyer (1991, 1992). Studies on the baited horse hair in sand and sea water resulted in the identification of Nia epidermoidea by Rosello et al. (1993). Ananda et al. (1998) revealed the occurrence of ten fungi on calcareous shells of three species (balanids, bivalves and Turritella), cuttle fish 'bone', exoskeleton of crabs and feathers collected from the sandy beaches along west coast of India. In another study, Ananda and Sridhar (2001) isolated 21 fungal species on animal substrates collected from mangrove habitats of Karnataka, India. They recorded Corollospora intermedia most frequently on calcareous shells and crab exoskeleton. Also, a great majority (15 species) of the fungi reported by them were terrestrial fungi.

Interestingly, majority of the marine fungi encountered during the study were arenicolous type. The appendaged ascospores and basidiospore aid in attaching them to the calcareous substrates. The decaying animal substrates consist of calcium carbonate, cellulose and keratin with an organic matrix. It is possible that the organic material might serve as nutrient source for the growth of marine fungi. The importance of higher fungi in the breakdown of animal substrates in the coastal environment is not clear because the number of observation and quantitative evaluation are limited. Hence, thorough search for microorganism in animal substrates should be undertaken to clarify their deterioration activities (Kohlmeyer \& Kohlmeyer 1979). The present study clearly supports the view of Ananda et al. (1998) that a prolonged incubation period i.e. 15-20 months are required for the calcareous animal substrates than woody substrates to record the colonized fungi. It is possible that the marine fungi requires extended incubation period on calcareous animal substrates than other substrates to elaborate the enzymes required to degrade the complex organic materials of animal substrates (Ananda et al. 1998).

\section{Acknowledgements}

Authors are thankful to the Principal and Management of Sir Syed College, Taliparamba, Kerala, India for providing facilities. They are also grateful to Board of Research in Nuclear Science (BRNS) Mumbai, Maharashtra, India for the financial support.

\section{References}

Ananda K, Sridhar KR. 2001. - Mycoflora on dead animal substrates of mangrove habitats of 
Karnataka coast, India. Sri Lanka Journal of Aquatic Science 6, 85-93.

Ananda K, Prasannarai K, Sridhar KR. 1998. - Occurrence of higher marine fungi on marine animal substrates of some beaches along the west coast of India. Indian Journal of Marine Science 27, 233-236.

Borse BD, Borse KN, Pawar NS, Tuwar AR. 2013. - Marine fungi from India- XII: A revised check list. Indian Journal of Geo-Marine Science 24, 110-118.

Hohnk W.1969. - Vber clen dilzlichen Befall Kalkiger Hartteile on Meerestieren. Ber. Dt. Wiss. Komm. Meeresforsch. 20,129-140.

Jones EBG, Sakayaroj J, Suetrong S, Somrithipol S, Pang KL. 2009. - Classification of marine Ascomycota, anamorphic taxa and Basidiomycota. Fungal Diversity 35, 1-187.

Jones EBG, Pilantanapak A, Chatmala I, Sakayaroj J, Phongpaichit S, Choeyklin R. 2006. - Thai marine fungal diversity. Songklamakarin Journal of Science and Technology 28, 687-708.

Kohlmeyer J. 1969. - The role of marine fungi in the penetration of calcareous substances. American Zoologist 9, 741-746.

Kohlmeyer J, Kohlmeyer E. 1979. - Marine Mycology: The Higher Fungi. Academic Press, New York, USA.

Kohlmeyer J, Volkmann-Kohlmeyer B. 1991. - Marine fungi of Queensland, Australia. Australian Journal of Marine Research 42, 91-99.

Kohlmeyer J, Volkmann-Kohlmeyer B. 1992. - Two ascomycotina from coral reef in the Caribbean and Australia. Cryptogamic Botany 2, 367-374.

Nambiar GR, Raveendran K. 2012. - An Introduction to the taxonomic studies of Indian Marine fungi. Malabar Natural History Society, Calicut, Kerala, India.

Raghukumar S. 1996 - Fungi in the marine realm: status, challenges and prospects. Kavaka 24, 2534.

Raveendran K, Manimohan P. 2007. - Marine Fungi of Kerala: A Preliminary Floristic and Ecological Study. Malabar Natural Historical Society, Calicut, Kerala, India.

Rees G, Jones EBG. 1985. -The fungi of coastal sand dune system. Botanica Marina 28, 213-220.

Rosello MA, Descals E, Cabrer B. 1993. - Nia epidermoidea, a new marine gasteromycete. Mycological Research 97, 68-70. 